Research Article

\title{
Knowledge, attitudes and practice survey about antimicrobial resistance and prescribing among physicians in a tertiary care teaching hospital in Eastern India
}

\begin{abstract}
Abhishek Ghosh $^{1}$, Tirthankar Deb ${ }^{2}$, Sanjana Ghosh $^{1}$
${ }^{1}$ Department of Pharmacology, College of Medicine \& JNM Hospital, Kalyani, Nadia, West Bengal, India,

${ }^{2}$ Department of Pharmacology, IQ city Medical College, Durgapur, West Bengal, India

Received: 6 December 2015

Revised: 9 January 2016

Accepted: 11 January 2016

*Correspondence to:

Dr. Abhishek Ghosh,

Email: drghosh.new@gmail.com

Copyright: (C) the author(s), publisher and licensee Medip Academy. This is an open-access article distributed under the terms of the Creative Commons Attribution Non-Commercial License, which permits unrestricted noncommercial use, distribution, and reproduction in any medium, provided the original work is properly cited.

ABSTRACT

Background: Antimicrobial resistance is a worldwide problem. Reduction in antimicrobial use is necessary to limit this problem. This can be addressed through changes in prescribing behaviour. Information about the driving forces behind antimicrobial prescription can be obtained by KAP (knowledge, attitudes and practice) surveys.

Methods: A self-administered 37 item questionnaire was distributed among doctors of different departments of College of Medicine \& JNM Hospital, Kalyani. It focused on their awareness about the current status of antimicrobial resistance, sources of information and training about use of Antimicrobials, confidence, factors influencing decisions and appropriateness of potential interventions.

Results: All doctors agreed that antimicrobial resistance is a problem in India and also in their daily practice. Doctors were lacking on the aspect of regular educational activities regarding appropriate use of antimicrobials, which they felt extremely important. Also many of them were unaware about the hospital formularies, current susceptibility pattern of common pathogens. Majority said that a local guideline would be more useful than the international one.

Conclusions: This survey identified topics to address in the containment of antimicrobials resistance like dissemination of information about local antimicrobial resistance rates, the revision and dissemination of local guidelines, and emphasization on regular educational activities among physicians.
\end{abstract}

Keywords: Antimicrobials, Resistance, Knowledge, Practice, Physicians

\section{INTRODUCTION}

Antimicrobial resistance is a worldwide problem preferentially affecting low - and middle income countries. ${ }^{1,2}$ Two main contributing factors are excessive use of antimicrobials and inadequate infection control policies facilitating spread of resistant microorganisms. ${ }^{3}$ Patients who receive inappropriate dose of antimicrobials are at more risk of acquiring infection from resistant microorganisms. ${ }^{4}$ Such infections commonly have increased mortality and morbidity. ${ }^{5}$ Reduction in antimicrobial use is necessary to limit this problem. This can be addressed through changes in prescribing behaviour. So knowledge about the driving forces behind antimicrobial prescription is needed. Such information can be obtained by means of KAP-surveys (knowledge, attitudes and practice surveys). KAP-surveys about antimicrobial resistance have been conducted among doctors in the community setting, but only few have been reported from the hospital setting. ${ }^{6,7}$

The bacterial disease burden in India is very high. So antibiotics play a huge role in controlling morbidity and mortality from such diseases. ${ }^{8}$ Recent reports on the emergence of "New Delhi metallo-beta-lactamase 1 gene" expressed by some gram negative Enterobacteriaceae has brought the problem of antibiotic overuse into the limelight. ${ }^{9}$ Still the optimal methods for addressing this problem is yet to be found. Such reforms may happen if there are fundamental changes in physicians' attitude. Studies have been done in past analyzing the prescription pattern of physicians. In a cross-sectional study, conducted in two tertiary care centres in the New Delhi ${ }^{10}$ in 2012 among 80 junior residents, $52.83 \%$ had received training regarding antibiotic prescription in last 6 months while $47.17 \%$ had not received any training in last 6 months. $88.7 \%$ 
believed that medical council should take strict actions prohibiting irrational use of antibiotics.

Top perceived barriers to appropriate antibiotic use were patient expectations, breaking old habits, and fear that patients would go elsewhere. Top strategies to overcome these barriers were patient educational materials, having guidelines accessible, and developing practice policies.

Similar to physicians from other parts of the world, our participants were aware of the growing challenge of antimicrobial resistance at local and national levels. Most, however, were unaware of the specific antimicrobial resistance rates and patterns in their own institutions. This may be the result of inadequate surveillance of the multi-drug resistant organisms or limited data sharing.

In India, the infectious disease burden is high. The recognition that resistance is caused in part by excessive antibiotic prescribing has prompted calls for reform. Such reforms require fundamental changes in physicians' attitude of antimicrobial use and a better understanding of their perceptions of antibiotic resistance. No study is yet to be conducted involving hospital doctors in India. So this study will give an idea about knowledge, attitude and practice of doctors of this institution regarding appropriate use of antimicrobials. This is important also to develop a hospital antibiotic policy.

So this study is an attempt to analyze the attitude and perception of doctors of different departments of a medical college concerning antibiotic prescribing.

\section{METHODS}

Study begun after getting clearance from Institutional Ethics Committee. All standards of good clinical practice were adhered including a detailed informed consent to participate in the study. Doctors of different clinical disciplines of College of Medicine \& JNM hospital, Kalyani were provided with the protocol and their consent for participation in the study was asked for.

Primary objective was to find out the knowledge, attitude and practice about antimicrobial prescription and resistance among doctors of different disciplines in College of Medicine \& JNM hospital, Kalyani, a tertiary care teaching hospital of West Bengal.

A self-administered questionnaire was distributed among doctors (attending physicians) of different clinical departments of the hospital after getting the approval of the Institutional Ethics Committee (IEC) and after they agreed to participate in the study. There was no incentive for subjects to participate. The questionnaire content was based on a previous survey described in the U.S. ${ }^{11}$ Prior to release, it was reviewed and standardized by a team of six Indian physicians to assess the relevance.
The 37-item questionnaire addressed the professional profile of the participants and frequency of antimicrobial prescription (5 questions), their awareness about the current status of antimicrobial resistance (6 questions), sources of information and training about use of antimicrobials ( 2 questions), confidence and seeking inputs (5 questions), factors influencing decisions around Antimicrobial prescription (4 questions) and the acceptability and appropriateness of potential interventions (6 questions) (Annexure 1).

Questions used a 4 or 5-point Likert scale (which includes answers ranging from "strongly agree" to "strongly disagree", from "very useful" to "not useful at all" and from "always" to "never"). The survey also included seven questions to assess basic knowledge about the clinical indications, spectrum, administration and pharmacology of antimicrobials.

The confidentiality of respondents and their choices were ensured.

We have used Likert items by combining the data into two categories, "strongly agree/agree", "very useful/useful" and "very confident/confident" versus the remaining options of the scale. Data was analysed with the software SPSS version 22 .

\section{RESULTS}

After getting answers of these 37 questions from 128 doctors, following results are obtained. $100 \%$ of the doctors agreed that antimicrobial resistance is a problem, in India and also in their daily practice.

Though frequency of prescribing antimicrobials vary in different physicians, 104 of all doctors $(81.25 \%)$ told that they review their decision to prescribe antimicrobials from a senior colleague while in the emergency room, outpatient department or wards and $53.12 \%$ of them had told that senior colleagues often recommend them a different antimicrobial.

46 doctors (35.94\%) felt very confident about themselves regarding the optimal use of antibiotics. 108 doctors $(84.37 \%)$ reported that in the last year, they had never received teaching on antibiotics as part of the academic activities in respective department and 112 doctors $(87.5 \%)$ had not participated in any course on antimicrobials during the last year (Table 1).

Table 1: Percentage of doctors attending class or course on antibiotics prescribing in last 1 year (out of 128 doctors).

\begin{tabular}{|lll|}
\hline & Yes & No \\
\hline $\begin{array}{l}\text { Attended class on } \\
\text { antibiotic prescription }\end{array}$ & $20(15.63 \%)$ & $108(84.37 \%)$ \\
\hline $\begin{array}{l}\text { Attended training } \\
\text { programme on } \\
\text { antibiotic use }\end{array}$ & $16(12.5 \%)$ & $112(87.5 \%)$ \\
\hline
\end{tabular}


While asking them about their source of information for antimicrobial use, $79.69 \%$ of them told that information from senior colleagues to be very useful, $81.25 \%$ agreed that information from colleagues of the same rank to be very helpful and $82.81 \%$ also find internet sources very useful. Regarding other sources, $4.69 \%$ feels that text books are very important source, other $4.69 \%$ told that medical journals are very important source and other $3.12 \%$ told antibiotic susceptibility pattern of the hospital are very important in decision making for prescribing antibiotics. But $10.94 \%$ doctors told that they feel that they have not enough sources of information about antibiotics (Table 2).

Table 2: What doctors felt about important source of information about antibiotics.

\begin{tabular}{|lll|}
\hline Sources & $\begin{array}{l}\text { Number of } \\
\text { doctors agreed } \\
\text { (out of 128) }\end{array}$ & Percentage \\
\hline $\begin{array}{l}\text { Information from } \\
\text { senior doctors }\end{array}$ & 102 & $79.69 \%$ \\
\hline $\begin{array}{l}\text { Information from } \\
\text { colleagues of same } \\
\text { rank }\end{array}$ & 104 & $81.25 \%$ \\
\hline Internet & 106 & $82.81 \%$ \\
\hline Text books & 6 & $4.69 \%$ \\
\hline Medical journals & 6 & $4.69 \%$ \\
\hline $\begin{array}{l}\text { Antibiotic } \\
\text { susceptibility } \\
\text { pattern of the } \\
\text { hospital }\end{array}$ & 4 & $3.12 \%$ \\
\hline $\begin{array}{l}\text { Feels that source } \\
\text { of information is } \\
\text { inadequate }\end{array}$ & 14 & $10.94 \%$ \\
\hline
\end{tabular}

Almost everyone (98.43\% of doctors) agreed that antibiotics were overused in their hospital as well as in other hospitals of India.

$59.37 \%$ of the doctors felt that it is difficult to select the correct antimicrobials. While choosing antibiotics, $45.31 \%$ of doctors said that their election of antibiotics is more affected by their availability while other $43.75 \%$ told that they give stress on the cause of the infection for choosing the correct drug.

$100 \%$ doctors agreed that patients, either in in-patient or in outpatients, demand for antibiotic prescription for their false belief that it would shorten duration of any illness, thus ultimately cause overuse and misuse of antibiotics.

$85.94 \%$ of the doctors said that development of a local guideline would be more useful than the international one. $10.94 \%$ of doctors felt that antibiotic guidelines are an obstacle more than a help to clinical care, while $84.37 \%$ of doctors disagreed about it.

$93.75 \%$ of doctors felt the importance of organizing educational programs on antibiotics.
$82.81 \%$ of doctors told that due to frequent changes in the hospital formulary, they never know about the list of available antibiotics in their hospital (Table 3).

\section{Table 3: Major obstacles in appropriate prescribing} of antimicrobials.

\begin{tabular}{|lll|}
\hline Obstacles & $\begin{array}{l}\text { Number of } \\
\text { doctors felt } \\
\text { (out of 128) }\end{array}$ & Percentage \\
\hline $\begin{array}{l}\text { Lack of local antibiotic } \\
\text { guidelines }\end{array}$ & 110 & $85.94 \%$ \\
\hline $\begin{array}{l}\text { Lack of antibiotic } \\
\text { educational } \\
\text { programmes }\end{array}$ & 120 & $93.75 \%$ \\
\hline $\begin{array}{l}\text { Frequent change of } \\
\text { hospital formulary }\end{array}$ & 106 & $82.81 \%$ \\
\hline
\end{tabular}

$9.37 \%$ of doctors told that unnecessary antibiotic use do not cause damage to patients while $81.25 \%$ of doctors disagreed about it. $65.62 \%$ of doctors felt that some antibiotics available in their hospital are of poor quality and less effective, while $4.69 \%$ of doctors disagreed and rest of the doctors remained neutral in this question.

While answering for different case scenario, response varied. In a simple diarrhoea of a 40 year old woman without fever, $57.81 \%$ doctors told that oral rehydration is sufficient but $40.62 \%$ opted for antibiotic use, either cotrimoxazole or ciprofloxacin (Table 4).

In an upper respiratory tract infection, $46.87 \%$ told about not using antibiotics but $53.13 \%$ opted for antibiotics, mostly cotrimoxazole followed by amoxicillin (Table 4).

Table 4: Response of doctors on using antibiotics in uncomplicated diarrhea and upper respiratory tract infection.

\begin{tabular}{|c|c|c|}
\hline & $\begin{array}{l}\text { No. of doctors } \\
\text { preferring } \\
\text { antibiotics }\end{array}$ & $\begin{array}{l}\text { No. of doctors } \\
\text { who would not } \\
\text { give antibiotics }\end{array}$ \\
\hline Simple diarrhoea & $52(40.62 \%)$ & $74(57.81 \%)$ \\
\hline $\begin{array}{l}\text { Uncomplicated } \\
\text { upper respiratory } \\
\text { tract infection }\end{array}$ & $68(53.13 \%)$ & $60(46.87 \%)$ \\
\hline
\end{tabular}

While asking about necessity of dose modification in chronic kidney disease patient for clindamycin and gentamicin, $81.25 \%$ told that dose modification was necessary for both of the drugs while $9.37 \%$ of them to change the dose for gentamicin only. Rest of the doctors didn't answer.

$9.37 \%$ of the doctors said ciprofloxacin is safe during pregnancy; rest of them opted for amoxicillin.

93.75\% had told metronidazole is the best antibiotic against the anaerobic bacteria. 
$56.25 \%$ had told that cephalosporins are not useful in MRSA (methicillin resistant Staphylococcus aureus) infection while $29.69 \%$ of doctors opted for the cephalosporins for treating MRSA.

$75 \%$ doctors told that ceftriaxone is the most effective drug to cross blood brain barrier while $12.55 \%$ opted for vancomycin and $7.81 \%$ had opted clindamycin.

\section{DISCUSSION}

In this study, all doctors agreed that antimicrobial resistance is a problem, in India and also in their daily practice. Only $35.94 \%$ felt very confident about themselves regarding the optimal use of antibiotics and a majority of them reviewed their decision from a senior colleague regarding appropriate choice of antimicrobials while in the emergency room, outpatient department or wards.

Continued medical educations and seminars, workshops on antimicrobial prescription are required for updating the knowledge of doctors and that would ultimately prevents result in inappropriate use of antimicrobials and emergence of resistance against them. Sadly $84.37 \%$ doctors in this study had never received teaching on antibiotics as part of the academic activities in respective department during the last year and $87.5 \%$ had not participated in any course on antimicrobials during the last year. Participation in such kind of educational activities must be emphasized to restrict inappropriate antimicrobial use.

The present survey also revealed information about the sources of information for antimicrobial use. Internet sources were ranked as the most useful source followed by information from the seniors and colleagues. A very small percentage had told about importance of text books, medical journals and antibiotic susceptibility pattern as the important sources. Only a few felt about not having enough sources of information about antibiotics, mainly because lack of information about susceptibility pattern in their community.

Most of them felt that some antibiotics available in their hospital are of poor quality and less effective, while only $4.69 \%$ of doctors disagreed. Few factors may be responsible for this. Despite regional and national regulations for drug marketing, counterfeit (and likely to be substandard) drugs have been found in India, but it is difficult to predict the magnitude of this problem. Also, generic drugs are frequently perceived to be less effective, an idea evidenced from recent studies from Columbia showing that generic vancomycin and oxacillin had a less therapeutic effect in animals..$^{12,13}$

The Indian Ministry of Health should build confidence in the quality of locally available antimicrobials by circulating adequate information about locally marketed drugs.
Over half of the doctors confessed about feeling difficulty to select the correct antimicrobials in specific situations. Only $43.75 \%$ gave stress on the cause of the infection for choosing the correct drug while other $45.31 \%$ of doctors said rely more on the availability of antimicrobials.

All doctors in this study agreed that patients or their keens, either in in-patient or in outpatients, demand for antibiotic prescription for almost all illness for their false belief that antibiotics would shorten duration of any illness, thus ultimately cause overuse and misuse of antibiotics. A study among parents and paediatricians in Venezuela revealed that $87 \%$ of doctors felt pressured by patients into prescribing antimicrobials. ${ }^{14}$

The high expectation about antimicrobials use from patients is very probably a consequence of their minimal understanding of antimicrobials resistance and their side effects. Education of the general public through community-targeted media information is extremely important.

Most of the doctors said that development of a local guideline would be more useful than the international one because of different susceptibility pattern of microbes in different regions but $10.94 \%$ of doctors felt that antibiotic guidelines are an obstacle more than a help to clinical care, may be because guidelines limit the clinical decision making to some extent.

Majority of doctors told that due to frequent changes in the hospital formulary is an obstacle because they are not informed about the changes and the list of available antibiotics in their hospital. So physicians must be well informed about the availability of antibiotics in their hospital to promote proper use. Though a great majority of doctors agreed that unnecessary antibiotic use cause damage to patients but $9 \%$ did not feel so.

While answering for different case scenario, response varied. In a simple diarrhoea of a 40 year old woman without fever, $40.62 \%$ opted for antibiotic use, either Cotrimoxazole or ciprofloxacin. In a upper respiratory tract infection, more than half opted for antibiotics, mostly Cotrimoxazole followed by amoxicillin. While asking about necessity of dose modification in chronic kidney disease patient for Clindamycin and gentamicin, only $9.37 \%$ answered correctly, i.e., not to change the dose for Clindamycin. $9.37 \%$ of the doctors lacked knowledge that ciprofloxacin is unsafe during pregnancy.

Similarly, $29.69 \%$ doctors did not know that cephalosporins are ineffective in MRSA infection. These findings suggest that this issue should be targeted in future educational interventions.

Most of them incorrectly estimated the local resistance rates of two key-pathogens in the hospital setting, $K$. pneumoniae and $P$. aeruginosa.

Similar findings have been described in other studies. 
Pulcini et al showed that only $16 \%$ of young doctors ${ }^{6,7}$ in a French hospital knew the actual proportion of community acquired- Escherichia coli resistant to fluoroquinolones. Local microbiology laboratories should maintain a database about the levels of resistance of key pathogens and communicate it to prescribers for their better orientation about current resistance and sensitivity patterns.

One of the main limitations of this kind of surveys is that participants may tend to give socially desirable answers rather than expressing their true opinions. These answers of questionnaire may not reflect what the doctors usually practice in real life. In order to minimize this potential bias, anonymous participation was ensured and the casebased questions about antimicrobials prescription were presented at the end of the survey.

\section{CONCLUSION}

To conclude, the present KAP-survey has generated information about the prescribing attitudes and practices of medical doctors from a government teaching hospital of India. It identified topics to address in the containment of antimicrobials resistance, such as the dissemination of information about local antimicrobial resistance rates, the importance of renewing public confidence in the quality of locally available antimicrobials, the revision and dissemination of local guidelines, and most importantly emphasization on regular educational activities among physicians regarding appropriate use of antimicrobials. This study is an attempt to analyze the attitude and perception of doctors of different departments of a medical college concerning antibiotic prescribing.

\section{ACKNOWLEDGEMENTS}

The authors acknowledge support from faculty doctors who participated in the study.

Funding: No funding sources Conflict of interest: None declared

Ethical approval: The study was approved by the Institutional Ethics Committee

\section{REFERENCES}

1. Levy SB. The challenge of antibiotic resistance. Sci Am. 1998;278:46-53.

2. Okeke IN, Laxminarayan R, Bhutta ZA, Duse AG, Jenkins P, O’Brien TF, Pablos-Mendez A, Klugman KP. Antimicrobial resistance in developing countries. Part I: recent trends and current status. Lancet Infect Dis. 2005;5(8):481-93.

3. Okeke IN: Poverty and root causes of resistance in developing countries. In antimicrobial resistance in developing countries. $1^{\text {st }}$ edition. Edited by: Sosa
AB, DK; Amabile-Cuevas, CF; Hsueh, PR; Kariuki, S; Okeke. IN New York: Springer;2010:27-36.

4. Costelloe C, Metcalfe C, Lovering A, Mant D, Hay $\mathrm{AD}$. Effect of antibiotic prescribing in primary care on antimicrobial resistance in individual patients: systematic review and meta-analysis. BMJ. 2010;340:c2096.

5. Shanthi M, Sekar U. Multi-drug resistant Pseudomonas aeruginosa and Acinetobacter baumannii infections among hospitalized patients: risk factors and outcomes. J Assoc Physicians India. 2009,57:636,8-40,5.

6. Guerra CM, Pereira CA, Neves Neto AR, Cardo DM, Correa L. Physicians' perceptions, beliefs, attitudes, and knowledge concerning antimicrobial resistance in a Brazilian teaching hospital. Infect Control Hosp Epidemiol. 2007,28(12):1411-4.

7. Pulcini C, Williams F, Molinari N, Davey P, Nathwani D. Junior doctors' knowledge and perceptions of antibiotic resistance and prescribing: a survey in France and Scotland. Clin Microbiol Infect. 2011,17(1):80-7.

8. Ganguly NK, Arora NK, Chandy SJ, Fairoze MN, Gill JP, Gupta U, et al. Rationalizing antibiotic use to limit antibiotic resistance in India. Indian $\mathrm{J}$ Med Res. 2011;134:281-94.

9. Al Khaja KA, Sequeira RP, Damanhori AH, Ismaeel AY, Handu SS. Antimicrobial prescribing trends in primary care: implications for health policy in Bahrain. Pharmacoepidemiol Drug Saf. 2008; 17:389-96.

10. Aggarwal S, Mathew J, Singh H, Sharma V. Attitude and perception of junior resident doctors' regarding antibiotic resistance - A pilot study, J Acute Dis. 2014; 2014:6-9

11. García C, Llamocca LP, Garcia K, et al. Knowledge, attitudes and practice survey about antimicrobial resistance and prescribing among physicians in a hospital setting in Lima, Peru. BMC Clin Pharmacol. 2011,11:8.

12. Vesga O AM, Salazar BE, Rodriguez CA, Zuluaga AF. Generic vancomycin products fail in vivo despite being pharmaceutical equivalents of the innovator. Antimicrob agents chemother. 2010,54(8):3271-9.

13. Rodriguez CA, Agudelo M, Zuluaga AF, Vesga O: In vitro and in vivo comparison of the antistaphylococcal efficacy of generic products and the innovator of oxacillin. BMC Infect Dis. 2010,10:153.

14. Nweihed L ML, Martin A: Influencia de los padres en la prescripcion de antibioticos hecha por los pediatras. Arch Venez Pueric Pediatr. 2002,65:21-7.

Cite this article as: Ghosh A, Deb T, Ghosh S. Knowledge, attitudes and practice survey about antimicrobial resistance and prescribing among physicians in a tertiary care teaching hospital in Eastern India. Int J Basic Clin Pharmacol 2016;5:1807. 
ANNEXURE

\section{Questionnaires:}

Please answer all questions as best you can and remember that all answers are anonymous.

\begin{tabular}{|c|c|c|}
\hline No. & Questions & Answer \\
\hline 1. & $\begin{array}{l}\text { After you left the medical school, how many years have you } \\
\text { been working in a hospital? (if you have worked in two or } \\
\text { more hospitals, please add the number of years in each } \\
\text { hospital) }\end{array}$ & \\
\hline 2 & Do you belong to which departments do? & \\
\hline 3. & Currently, what position do you have in the hospital? & $\square$ Resident $\square$ Attending physician \\
\hline 4. & $\begin{array}{l}\text { Do you think that knowledge of antibiotics will be } \\
\text { important to you in your medical career (currently and in } \\
\text { the future)? }\end{array}$ & $\square$ Yes $\square$ No \\
\hline 5. & What do you think about antimicrobial resistance? & $\begin{array}{l}\square \text { It is a problem } \square \text { It is not a problem } \\
\square \text { I do not know }\end{array}$ \\
\hline 6. & $\begin{array}{l}\text { How frequent do you prescribe antibiotics in the emergency } \\
\text { room, outpatient clinic or in the wards? }\end{array}$ & $\begin{array}{l}\square \text { More than once a day } \square \text { Once a day } \\
\square \text { 3-5 times per week } \square 1-2 \text { times per week } \square \text { Less } \\
\text { than once a week }\end{array}$ \\
\hline \multicolumn{3}{|c|}{ The following questions are about how you choose antibiotics } \\
\hline 7. & $\begin{array}{l}\text { When you are in the emergency room, outpatient clinic or } \\
\text { in the wards, how frequent do you review your decision to } \\
\text { prescribe antibiotics with a senior colleague? }\end{array}$ & $\begin{array}{l}\square \text { Never } \square \text { Sometimes } \\
\square \text { About half the time } \square \text { Most of the time } \\
\square \text { Always }\end{array}$ \\
\hline 8. & $\begin{array}{l}\text { If you ask to a senior colleague, how frequent he/she } \\
\text { recommends you a different antibiotic? }\end{array}$ & $\begin{array}{l}\square \text { Never } \square \text { Sometimes } \\
\square \text { About half the time } \square \text { Most of the time } \\
\square \text { Always }\end{array}$ \\
\hline 9. & $\begin{array}{l}\text { How confident do you feel about the optimal use of } \\
\text { antibiotics? }\end{array}$ & $\begin{array}{l}\square \text { Very confident } \square \text { Somewhat confident } \\
\square \text { Somewhat unconfident } \square \text { Unconfident }\end{array}$ \\
\hline \multicolumn{3}{|c|}{ The following questions are about how you learn about antibiotics } \\
\hline \multirow{3}{*}{10} & $\begin{array}{l}\text { During the last year, how many times have you received } \\
\text { some teaching on antibiotics...? }\end{array}$ & \\
\hline & - As part of the academic activities of your department & $\begin{array}{l}\square 0 \square 1-3 \text { times } \\
\square 4-6 \text { times } \square 6-10 \text { times } \\
\square>10 \text { times }\end{array}$ \\
\hline & - Participation of courses & $\begin{array}{l}\square 0 \square 1-3 \text { times } \\
\square 4-6 \text { times } \square 6-10 \text { times } \\
\square>10 \text { times }\end{array}$ \\
\hline \multirow{5}{*}{11.} & $\begin{array}{l}\text { Which of the following sources of information do you use } \\
\text { as part of continuous medical education on antibiotics or } \\
\text { when you have a specific question on antibiotics? Please } \\
\text { check your rating n terms of its usefulness with } 1=\text { being } \\
\text { very useful, } 3 \text { = useful and } 5=\text { not at all. If you are not } \\
\text { familiar with a source, please check that option }\end{array}$ & \\
\hline & A) Information from senior colleagues & $\begin{array}{l}\square 1 \square 2 \square 3 \square 4 \square 5 \\
\square \text { Not familiar with }\end{array}$ \\
\hline & B) Information from colleagues of the same rank & $\begin{array}{l}\square 1 \square 2 \square 3 \square 4 \square 5 \\
\square \text { Not familiar with }\end{array}$ \\
\hline & C) Internet sources & $\begin{array}{l}\square 1 \square 2 \square 3 \square 4 \square 5 \\
\square \text { Not familiar with }\end{array}$ \\
\hline & D) Others : please write it out & \\
\hline 12. & $\begin{array}{l}\text { Do you think you have enough sources of information about } \\
\text { antibiotics when you need it? }\end{array}$ & $\begin{array}{l}\square \text { Yes } \square \text { No, should be more sources of information } \\
\text { (please specify which sources do you think would be } \\
\text { useful): ............ }\end{array}$ \\
\hline
\end{tabular}




\begin{tabular}{|c|c|c|}
\hline 13. & $\begin{array}{l}\text { Antibiotics are overused in my hospital and in other } \\
\text { hospitals of my country }\end{array}$ & $\begin{array}{l}\square \text { Strongly agree } \square \text { Agree } \\
\square \text { Neutral } \square \text { Disagree } \square \text { Strongly disagree }\end{array}$ \\
\hline 14. & Antibiotics are overused in the community in India & $\begin{array}{l}\square \text { Strongly agree } \square \text { Agree } \\
\square \text { Neutral } \square \text { Disagree } \square \text { Strongly disagree }\end{array}$ \\
\hline 15. & I believe it is difficult to select the correct antibiotic & $\begin{array}{l}\square \text { Strongly agree } \square \text { Agree } \\
\square \text { Neutral } \square \text { Disagree } \square \text { Strongly disagree }\end{array}$ \\
\hline 16. & $\begin{array}{l}\text { Antimicrobial resistance is not a significant problem in my } \\
\text { hospital }\end{array}$ & $\begin{array}{l}\square \text { Strongly agree } \square \text { Agree } \\
\square \text { Neutral } \square \text { Disagree } \square \text { Strongly disagree }\end{array}$ \\
\hline 17. & $\begin{array}{l}\text { When I decide which antibiotic to use, my election is more } \\
\text { affected by the expiration date/availability than the cause of } \\
\text { the infection. }\end{array}$ & $\begin{array}{l}\square \text { Strongly agree } \square \text { Agree } \\
\square \text { Neutral } \square \text { Disagree } \square \text { Strongly disagree }\end{array}$ \\
\hline \multirow{3}{*}{18.} & \multicolumn{2}{|l|}{ Patients' demands for antibiotics contribute to overuse... } \\
\hline & a- in inpatients & $\begin{array}{l}\square \text { Strongly agree } \square \text { Agree } \\
\square \text { Neutral } \square \text { Disagree } \square \text { Strongly disagree }\end{array}$ \\
\hline & b- in outpatients & $\begin{array}{l}\square \text { Strongly agree } \square \text { Agree } \\
\square \text { Neutral } \square \text { Disagree } \square \text { Strongly disagree }\end{array}$ \\
\hline 19. & $\begin{array}{l}\text { General knowledge on antimicrobial resistance should be } \\
\text { considered when antibiotics are prescribed to an individual } \\
\text { patient }\end{array}$ & $\begin{array}{l}\square \text { Strongly agree } \square \text { Agree } \\
\square \text { Neutral } \square \text { Disagree } \square \text { Strongly disagree }\end{array}$ \\
\hline 20. & $\begin{array}{l}\text { The development of a local guidelines would be more } \\
\text { useful than the international ones }\end{array}$ & $\begin{array}{l}\square \text { Strongly agree } \square \text { Agree } \\
\square \text { Neutral } \square \text { Disagree } \square \text { Strongly disagree }\end{array}$ \\
\hline 21. & $\begin{array}{l}\text { Antibiotic guidelines and antibiotic committee are an } \\
\text { obstacle more than a help to clinical care }\end{array}$ & $\begin{array}{l}\square \text { Strongly agree } \square \text { Agree } \\
\square \text { Neutral } \square \text { Disagree } \square \text { Strongly disagree }\end{array}$ \\
\hline 22. & $\begin{array}{l}\text { I would like the organization of educational programs on } \\
\text { antibiotics }\end{array}$ & $\begin{array}{l}\square \text { Strongly agree } \square \text { Agree } \\
\square \text { Neutral } \square \text { Disagree } \square \text { Strongly disagree }\end{array}$ \\
\hline 23. & $\begin{array}{l}\text { I never know which antibiotics are available in my hospital } \\
\text { because the formulary always changes }\end{array}$ & $\begin{array}{l}\square \text { Strongly agree } \square \text { Agree } \\
\square \text { Neutral } \square \text { Disagree } \square \text { Strongly disagree }\end{array}$ \\
\hline 24. & $\begin{array}{l}\text { I believe that prescribing antimicrobial does not cause } \\
\text { damage when patients do not need them }\end{array}$ & $\begin{array}{l}\square \text { Strongly agree } \square \text { Agree } \\
\square \text { Neutral } \square \text { Disagree } \square \text { Strongly disagree }\end{array}$ \\
\hline 25. & $\begin{array}{l}\text { I suspect that some antibiotics available in my hospital are } \\
\text { of poor quality and for that reason do not work. }\end{array}$ & $\begin{array}{l}\square \text { Strongly agree } \square \text { Agree } \\
\square \text { Neutral } \square \text { Disagree } \square \text { Strongly disagree }\end{array}$ \\
\hline \multicolumn{3}{|c|}{ Tell us how strongly you agree or disagree with the following statements on antimicrobial resistance } \\
\hline 26. & Antimicrobial resistance is a problem worldwide? & $\begin{array}{l}\square \text { Strongly agree } \square \text { Agree } \\
\square \text { Neutral } \square \text { Disagree } \square \text { Strongly disagree }\end{array}$ \\
\hline 27 & Antimicrobial resistance is a problem in my country & $\begin{array}{l}\square \text { Strongly agree } \square \text { Agree } \\
\square \text { Neutral } \square \text { Disagree } \square \text { Strongly disagree }\end{array}$ \\
\hline 28. & Antimicrobial resistance is a problem in my daily practice & $\begin{array}{l}\square \text { Strongly agree } \square \text { Agree } \\
\square \text { Neutral } \square \text { Disagree } \square \text { Strongly disagree }\end{array}$ \\
\hline \multicolumn{3}{|c|}{ The following questions are related to the use of antibiotics and the rates of antimicrobial resistance } \\
\hline 29. & $\begin{array}{l}\text { A } 40 \text { year-old woman went to the Emergency room } \\
\text { complaining of } 4 \text { days of diarrhea ( } 3 \text { unformed stools per } \\
\text { day). No history of fever. One month before she had a } \\
\text { urinary tract infection and took ciprofloxacin. . Which } \\
\text { antibiotic will you recommend? }\end{array}$ & $\begin{array}{l}\square \text { Ciprofloxacin } \\
\square \text { Trimethoprim-sulfamethoxazole } \\
\square \text { No need of antibiotic use. Oral rehydration. }\end{array}$ \\
\hline 30. & $\begin{array}{l}\text { A } 32 \text { year-old male went to the clinic complaining of fever } \\
\left(39^{\circ} \mathrm{C}\right) \text {, nasal discharge and throat pain for } 3 \text { days. Which } \\
\text { antibiotic will you recommend? }\end{array}$ & $\begin{array}{l}\square \text { Amoxicillin } \square \text { Clarithromycin } \\
\square \text { Trimethoprim-sulfamethoxazole } \\
\square \text { No need of antibiotic use }\end{array}$ \\
\hline 31. & $\begin{array}{l}\text { During your stay in the ward, you have seen two patients } \\
\text { with impaired kidney function. Patient A is a } 68 \text { year-old } \\
\text { male with cellulitis in the lower limb. He received } \\
\text { clindamycin. Patient B is a } 64 \text { year-old woman with } \\
\text { diabetes who received empirically treatment for sepsis with } \\
\text { ceftriaxone and gentamicin. In which case you will need to } \\
\text { adjust the antibiotic dose? }\end{array}$ & $\begin{array}{l}\square \text { Patient A } \square \text { Patient B } \\
\square \text { Patient A and B } \\
\square \text { Neither patient A nor patient B }\end{array}$ \\
\hline 32. & Which one of the following antibiotics may be safe during & $\square$ Amoxicillin $\square$ Ciprofloxacin $\square$ Gentamicin \\
\hline
\end{tabular}


pregnancy?

Which one of the following antibiotics has the best activity $\square$ Ciprofloxacin

33. against anaerobes?

$\square$ Metronidazole

$\square$ Trimethoprim-sulfamethoxazole

34. Methicillin resistant - Staphylococcus aureus is susceptible Cefalotin $\square$ Cefuroxime to:

$\square$ Ceftriaxone $\square$ None of these antibiotics

35. Which one of the following antibiotic is more effective to $\square$ Clindamycin $\square$ Ceftriaxone cross the blood-brain barrier? Vancomycin

\section{Knowledge about burden of resistance in community}

36. The rate of resistance of Klebsiella pneumoniae to $>50 \% \square 20 \%-50 \%$ cephalosporins in your hospital is .... $\square 20 \% \square$ I do not know

37. The rate of resistance of Pseudomonas aeruginosa to $>50 \% \square 20 \%-50 \%$ ciprofloxacin in your hospital is ... 